\title{
Bumblebees (Hymenoptera, Apidae, Bombus Latr.) of the thermal spring Pymvashor, north-east of European Russia
}

\author{
Yulia Sergeevna Kolosova, Grigory Sergeevich Potapov, Natalia Garyevna Skyutte \\ \& Ivan Nikovaevich Bolotov
}

Kolosova, Yu. S., Potapov, G. S., Skyutte, N. G. \& Bolotov, I. N. 2016: Bumblebees (Hymenoptera, Apidae, Bombus Latr.) of the thermal spring Pymvashor, north-east of European Russia. — Entomol. Fennica 27: 190-196.

A bumblebee community was studied at Pymvashor, the only thermal spring in North European Russia. The bumblebee fauna comprised 12 species, which is a large number when compared to other native tundra ecosystems. Most of the species recorded were ubiquitous, 3 were forest species and 2 were typical tundra species. The presence of the ubiquitous and forest species in the bumblebee community appears to be due to the landscape features and the perennial impact of the hot springs, under the influence of which specific extrazonal ecosystems arise that are different from those typical of the tundra zone.

Yu. S. Kolosova, G. S. Potapov, N. G. Skyutte \& I. N. Bolotov, Federal Center for Integrated Arctic Research, Russian Academy of Sciences, Naberezhnaya Severnoy Dviny 23, 163000 Arkhangelsk, Russia; Corresponding authors' email:kolosova_arkh@mail.ru,grigorij-potapov@yandex.ru

Received 23 March 2016, accepted 5 October 2016

\section{Introduction}

The study of invertebrates, including insects in hydrothermal ecosystems, has always been of great interest. There is a large body of literature dedicated to research of different taxonomic groups of insects at thermal springs in different regions. This research has considered the impact of hot springs on the species richness of insects, adaptation to the specific conditions of thermal waters, ecology of different species, etc. (Stockner 1971, Resh \& Barnby 1984, Glazier \& Gooch 1987, Pritchard 1991, Pritchard \& Kortello 1997, Lobkova \& Lobkov 2003, Garbuz et al. 2008).

The stimulus for our research at the thermal spring of Pymvashor was that the hydrothermal system is located within the southern tundra, and characterised by a unique composition of flora and fauna (Bolotov \& Bogolitsyn 2011). Many groups have not previously been studied in this area. As the object of our research, we chose bumblebees, a taxonomic group with origins in the mountains of Central Asia (Hines 2008). Hence, bumblebees are well adapted to living in the unfavourable climatic conditions of the north. The present article describes the bumblebee community at Pymvashor.

\section{Materials and methods}

The thermal spring Pymvashor $\left(67^{\circ} 09^{\prime} \mathrm{N}, 60^{\circ} 51^{\text {' }}\right.$ E) is located in the Nenets Autonomous Region, on the eastern outskirts of the Bolshezemelskaya tundra, near both the Adzva River and the right tributary of the Usa River. It is in the subzone of 


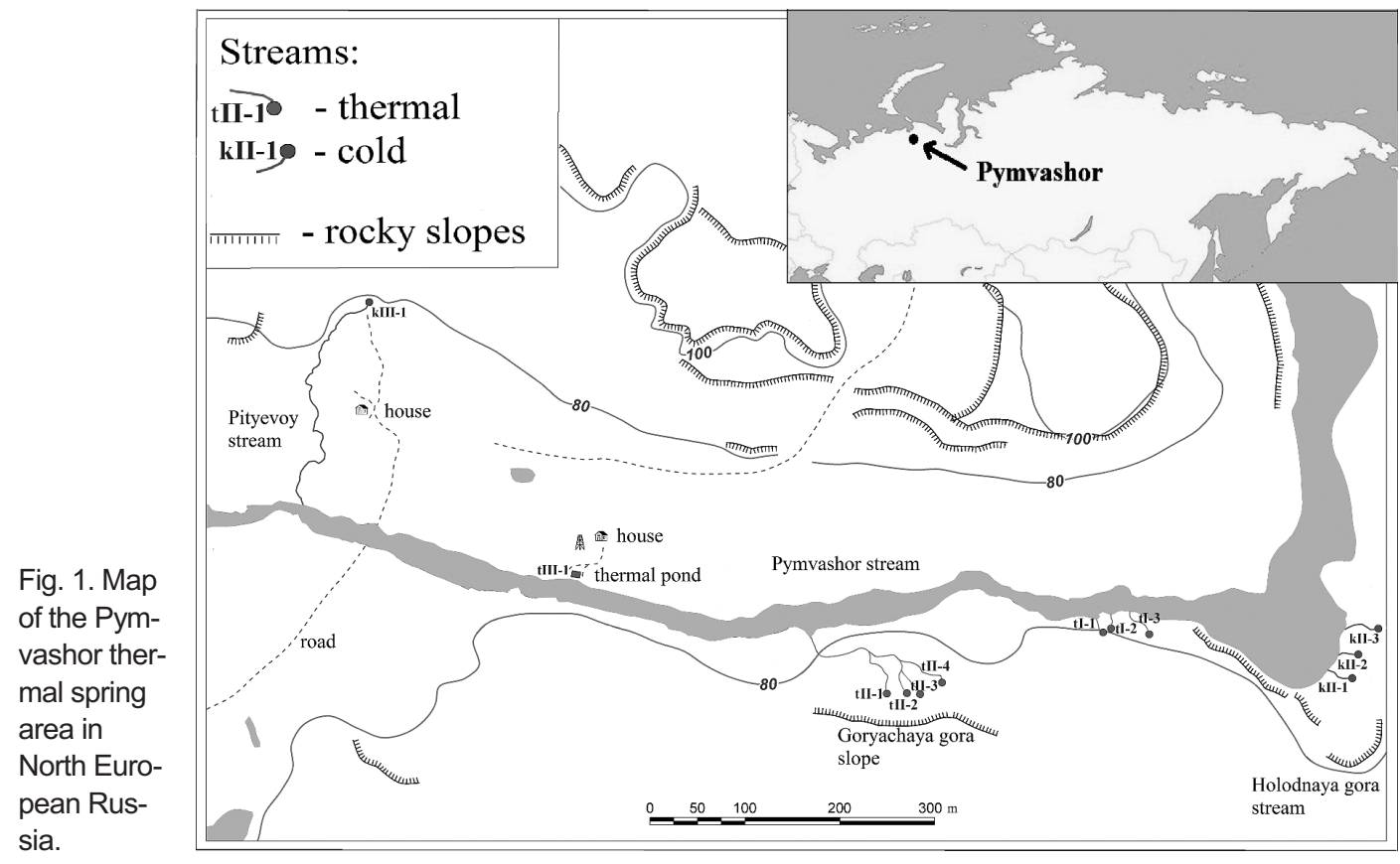

the dwarf-shrub tundra. Pymvashor is the only territory of the mainland northern Europe where thermal springs exist, and is located to the north of the Arctic Circle (Bolotov \& Bogolitsyn 2011). Descriptions of the natural conditions, physical and geographic characteristics of the study area were published earlier (Bolotov \& Bogolitsyn 2011, Bolotov et al. 2012). A map of the thermal spring area of Pymvashor is presented in Fig. 1.

The zonal vegetation of the study area is represented mainly by different variants of dwarf birch and willow tundra. However, under the influence of the warming impact of thermal water it has formed an extrazonal ecosystem (Vinogradova 1962) which is characterised by more southern types of vegetation, represented by sparse spruce-woods (Picea abies ssp. obovata (Ledeb.) Domin). These grow as a narrow band through the thermal valley (Bolotov \& Bogolitsyn 2011, Bolotov et al. 2012). There are a large number of plant species of the taiga flora: Cirsium heterophyllum (L.) Hill, Filipendula ulmaria (L.) Maxim., Hieracium umbellatum L., Chamerion angustifolium (L.) Holub, Veronica longifolia L. and Vicia sepium L. The nomenclature of plants follows Elven (2016).

Entomological studies were conducted as part of the Polar Expedition of the Institute of Envi- ronmental Problems of the North (Russian Academy of Sciences, Ural Division) in years 2009, 2010, and 2012-14. Bumblebees were collected using an entomological net, within the area of the thermal spring in the valley and on the banks of the Pymvashor stream. A total of 233 bumblebees were collected.

Bumblebee identification followed Løken $(1973,1984)$ and Panfilov (1978). The subgeneric classification and the synonymy of species are given according to Williams (2016). Our determinations were verified using the collection materials from the Natural History Museum (London) and the Zoological Institute of the Russian Academy of Sciences (Saint Petersburg).

Identification of species of the Bombus lucorum-complex followed the keys of Rasmont (1984), Rasmont and Terzo (2010), and without using DNA-barcoding. However, we have to consider our specimens as $B$. cf. cryptarum, because morphological identification of these species is unreliable (Bossert 2015). It is most likely that $B$. cryptarum is represented at Pymvashor. Rasmont and Iserbyt (2010) note that "according to Pamilo et al. (1997) and to many personal observations, $B$. cryptarum may totally supplant $B$. lucorum north of the Arctic Circle".

The distributions of the bumblebee species 
Table 1. Species of bumblebees and their relative abundances (\%) in Pymvashor, North European Russia, in different years.

\begin{tabular}{lccc}
\hline & 2010 & 2012 & 2013 \\
\hline B. (Megabombus) hortorum (Linnaeus, 1761) & 3.5 & 1.0 & 2.4 \\
B. (Thoracobombus) pascuorum (Scopoli, 1763) & - & - & 7.1 \\
B. (Th.) schrencki Morawitz, 1881 & 1.2 & - & - \\
B. (Psithyrus) flavidus Eversmann 1852 & 79.0 & 31.2 & 16.7 \\
B. (Ps.) sylvestris (Lepeletier, 1832) & 1.2 & - & - \\
B. (Pyrobombus) lapponicus (Fabricius, 1793) & - & 4.2 & 21.4 \\
B. (Pr.) hypnorum (Linnaeus, 1758) & - & 4.2 & - \\
B. (Pr.) pratorum (Linnaeus, 1761) & 4.6 & 26.0 & 7.1 \\
B. (Pr.) jonellus (Kirby, 1802) & 4.6 & 18.8 & 2.4 \\
B. (Pr.) cingulatus Wahlberg, 1854 & 1.2 & 5.2 & 3.8 \\
B. (Alpinobombus) balteatus Dahlbom, 1832 & 3.5 & 5.2 & - \\
B. (Bombus) cf. cryptarum (Fabricius, 1775) & 1.2 & 4.2 & 42 \\
\hline Number of specimens & 86 & 96 & \\
\hline
\end{tabular}

are based on the data of Pekkarinen and Teräs (1993), Byvaltsev (2009), Levchenko and Tomkovich (2014), and Williams (2016). The main habitats of the bumblebee species are according to Bäckman and Tiainen (2002), and Bolotov and Kolosova (2006).

The relative abundance of each species of bumblebee was taken to be equal to the proportion of each species caught (Magurran 2004). The relative abundance was calculated for each year separately. The periods of collecting were from 28.VIII to 4.IX.2010, from 31.VII to 5.VIII 2012, and 4-16.VII.2013. The specimens of 2009 and 2014 were excluded from the calculations (and Table 1), because there were only few bumblebees (9 individuals).

The specimens of bumblebees from Pymvashor are deposited in the Russian Museum of the Biodiversity Hotspots (RMBH), Federal Center for Integrated Arctic Research, Arkhangelsk, Russia.

\section{Results}

The bumblebee fauna of the thermal spring of Pymvashor was represented by 12 species. The study area was dominated by Transpalaearctic species (58\%), while Holarctic ones accounted for $25 \%$, and Eurosiberian ones $17 \%$. According to their habitat preferences, most species are considered ubiquitous $(58 \%)$, while forest species accounted for $25 \%$, and tundra species $17 \%$ of the total. As estimated from the proportion of each species caught, the relative abundance of each bumblebee species at Pymvashor thermal spring is given in Table 1. The most abundant species in the period from 28.VIII to 4.IX.2010 was $B$. flavidus (79\%); other species in the community were rare. The period from 31.VII to 5.VIII.2012 was dominated $B$. flavidus $(31.2 \%)$, B. pratorum (26\%) and B. jonellus (18.8\%). Bombus balteatus (38.1\%), B. lapponicus $(21.4 \%)$ and B. flavidus $(16.7 \%)$ were the most abundant species in the community in 4-16.VII.2013.

In the list of the examined material presented below, we note the numbers of individuals, the dates of the records, the localities within the study area, and the collector name in brackets. Queens of bumblebees are marked as $\circ$, workers $\not{q}$, and males ${ }^{\lambda}$.

\subsection{Bombus (Megabombus) hortorum (Linnaeus, 1761)}

Examined material. 18 28.VIII.2010, bank of the Pymvashor stream, [Bolotov]; $1 \overbrace{}^{\Uparrow}$ 30.VIII. 2010, valley of the Pymvashor stream, [Bolotov]; 1ช 4.IX.2010, valley of the Pymvashor stream, near to the house, [Bolotov]; 1ช̧ 3.VIII.2012, valley of the Pymvashor stream, near to the Iglovsky snowfield, [Skyutte]; 1ช 9.VII.2013, valley of the Pymvashor stream, near to the house, [Skyutte]. 
Distribution. Transpalaearctic.

Main habitat requirement. Ubiquitous.

\subsection{Bombus (Thoracobombus) pascuorum (Scopoli, 1763)}

Examined material. 3ళ 14.VII.2013, near to the thermal pond, [Skyutte].

Distribution. Transpalaearctic.

Main habitat requirement. Ubiquitous.

\subsection{Bombus (Thoracobombus) schrencki Morawitz, 1881}

Examined material. $1 \lesssim 28$.VIII.2010, bank of the Pymvashor stream, [Bolotov].

Distribution. Transpalaearctic.

Main habitat requirement. Forest.

\subsection{Bombus (Psithyrus) flavidus Eversmann 1852}

Examined material. 31 $\overbrace{}^{\Uparrow}$ 28.VIII.2010, bank of the Pymvashor stream, [Bolotov]; 80 28.VIII.2010, 7ठ 30.VIII.2010, valley of the Pymvashor stream, [Bolotov]; $7 \AA$ 30.VIII.2010, $1 \delta$ 4.IX.2010, valley of the Pymvashor stream, [Bolotov]; $13 ð$ 28.VIII.2010, Goryachaya gora slope, [Bolotov]; 2§ 1.VIII.2012, near to the Pityevoy stream, [Skyutte]; 13ð 31.VII.2012, 9 수 1.VIII.2012, 5 5.VIII.2012, valley of the Pymvashor stream, near to the house, [Skyutte]; $2 \hat{\gamma}$ 14.VII.2013, near to the thermal pond, [Skyutte]; 50 15.VII.2013, valley of the Pymvashor stream, [Skyutte].

Distribution. Holarctic.

Main habitat requirement. Ubiquitous.

\subsection{Bombus (Psithyrus) sylvestris (Lepeletier, 1832)}

Examined material. 1ठ 30.VIII.2010, valley of the Pymvashor stream, [Bolotov].

Distribution. Transpalaearctic.

Main habitat requirement. Ubiquitous.

\subsection{Bombus (Pyrobombus) lapponicus (Fabricius, 1793)}

Examined material. 1ל 23.VII.2009, bank of the Pymvashor stream, [Bolotov]; 1ช $2 \hat{\jmath} 31$.VII. 2012, $1 \delta^{\Uparrow}$ 1.VIII.2012, valley of the Pymvashor stream, near to the house, [Skyutte]; $1 \delta^{\lambda}$ 10.VII.2013, Goryachaya gora slope, [Skyutte]; 2ఫ 10 14.VII.2013, valley of the Pymvashor stream, near to the house, [Skyutte]; 4ఫ్ 15.VII. 2013, valley of the Pymvashor stream, [Skyutte]. Distribution. Transpalaearctic.

Main habitat requirement. Tundra.

\subsection{Bombus (Pyrobombus) hypnorum (Linnaeus, 1758)}

Examined material. 2ఫ̛ 1ठ 31.VII.2012, $1 \widehat{\jmath}$ 1.VIII.2012, valley of the Pymvashor stream, near to the house, [Skyutte].

Distribution. Transpalaearctic.

Main habitat requirement. Ubiquitous.

\subsection{Bombus (Pyrobombus) pratorum (Linnaeus, 1761)}

Examined material. 1ठ28.VIII.2010, bank of the Pymvashor stream, [Bolotov]; 1 ㅇ 1ช 30.VIII. 2010, valley of the Pymvashor stream, [Bolotov]; 1\% 4.IX.2010, valley of the Pymvashor stream, near to the house, [Bolotov]; 1ర్ 1.VIII.2012, 300 $\mathrm{m}$ from the house, near to the karst zone (kIII), [Skyutte]; 1ర 1ठ 1.VIII.2012, near to the Pityevoy stream, [Skyutte]; $2 \hat{\jmath}$ 1.VIII.2012, near to the karst zone (kII); 1 7 7ð 31.VII.2012, 2ఫ $6{ }^{\lambda}$

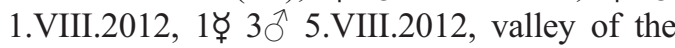
Pymvashor stream, near to the house, [Skyutte]; 3ซ 14.VII.2013, near to the thermal pond, [Skyutte].

Distribution. Eurosiberian.

Main habitat requirement. Forest.

\subsection{Bombus (Pyrobombus) jonellus (Kirby, 1802)}

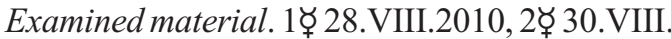
2010, valley of the Pymvashor stream, [Bolotov]; 
1t 30.VIII.2010, valley of the Pymvashor

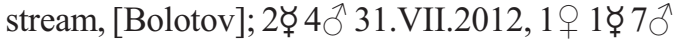
1.VIII.2012, $2{ }^{\lambda}$ 5.VIII.2012, valley of the Pymvashor stream, near to the house, [Skyutte]; 1ל VIII.2012, valley of the Pymvashor stream, [Skyutte].

Distribution. Holarctic.

Main habitat requirement. Ubiquitous.

\subsection{Bombus (Pyrobombus) cingulatus Wahlberg, 1854}

Examined material. 1రఫ 30.VIII.2010, valley of the Pymvashor stream, [Bolotov]; $1 \hat{\sigma} 31$.VII.

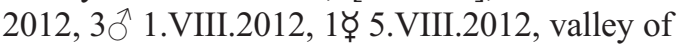
the Pymvashor stream, near to the house, [Skyutte]; 2ఫ 14.VII.2013, near to the thermal pond, [Skyutte].

Distribution. Eurosiberian.

Main habitat requirement. Forest.

\subsection{Bombus (Alpinobombus) balteatus Dahlbom, 1832}

Examined material. 19 28.VIII.2010, valley of the Pymvashor stream, [Bolotov]; 1 + 30.VIII. 2010, valley of the Pymvashor stream, [Bolotov]; 1\% 28.VIII.2010, on the slope of Goryachaya

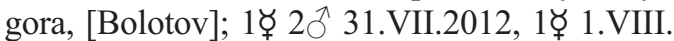
2012, 1ఫ 5.VIII.2012, 1ఫ 9.VII.2013, valley of the Pymvashor stream, near to the house, [Skyutte]; 3\% 10.VII.2013, on the slope of Goryachaya gora, [Skyutte]; 2 ㅇ 4ఫ 1ð 14.VII.2013, near to the thermal pond, [Skyutte]; 1916 .VII. 2013, near to the rocky slope, [Skyutte]; $196 \%$ $1 \lesssim 25$.VII.2014, valley of the Pymvashor stream, near to the house, [Skyutte].

Distribution. Transpalaearctic.

Main habitat requirement. Tundra.

\subsection{Bombus (Bombus) cf. cryptarum} (Fabricius, 1775)

Examined material. 1ఫ 28.VIII.2010, on the bank of the Pymvashor stream, [Bolotov]; 1ช

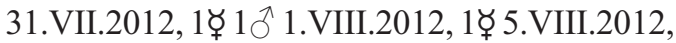
valley of the Pymvashor stream, near to the house, [Skyutte].
Distribution. Holarctic.

Main habitat requirement. Ubiquitous.

\section{Discussion}

There are two main factors that appear to be responsible for the species composition and abundance of bumblebees in the Pymvashor thermal spring area. The first one is the geothermal heating, i.e. there are the specific climatic conditions, different from the zonal tundra habitats. The second factor is that the formation of bumblebee communities is influenced by extrazonal ecosystems in the thermal area.

Due to the combined effects of these two factors, the bumblebee fauna in Pymvashor has quite a high number of ubiquitous and forest species, which are not typical of zonal tundra habitats. Furthermore, the number of recorded species (12) is higher than in other localities within the tundra zonal habitats of North European Russia (Potapov et al. 2014b).

However, the fauna of bumblebees in the surrounding areas has been poorly studied, because they are hard-to-reach. The materials represent mainly the early $20^{\text {th }}$ century in the collections of the Zoological Institute of Saint-Petersburg (Panfilov 1981, 1982, 1984). According to old collections, only five species have been found in these areas: B. lapponicus, B. hypnorum, B. pratorum, $B$. jonellus, $B$. balteatus. During our research, we did not study the territories near Pymvashor.

The bumblebee fauna of Pymvashor includes species that are widely distributed in the Palaearctic, which indicates the low specificity of the community. It contains two typical tundra species, B. balteatus and B. lapponicus. Their abundances were not high in the late summer 2010 and 2012 but they dominated in the community in the middle July 2013 (Table 1).

The forest species in the bumblebee fauna of the study area include $B$. schrencki, $B$. pratorum and $B$. cingulatus. These species are common within the taiga zone of the European North of Russia, but are not typical for tundra habitats (Bolotov \& Kolosova 2006).

The presence of the ubiquitous $B$. hortorum is noteworthy, as it is usually characteristic of 
meadow communities (Bolotov \& Kolosova 2006). The other ubiquitous species, B. jonellus, is a typical representative of the bumblebee fauna at high latitudes (Chernov 1966, Bolotov \& Podbolotskaya 2003). The presence of B. flavi$d u s$, which is a social parasite of $B$. jonellus, was expected (Løken 1984). Its relative abundance in the community was very high, $79 \%$ in 2010 (Table 1). Such high values of abundance may be explained by the fact that we collected bumblebees in the late summer of 2010, which is the period for the flight activity of $B$. flavidus males (Løken 1984). In 2012 and 2013, when the collecting period was in the middle summer or close to it, the relative abundance of $B$. flavidus was lower.

Unfortunately, we have no possibilities to compare the relative abundance of species between Pymvashor and the surrounding areas, because there is few information from there. We can assume that the bumblebees develop more rapidly in Pymvashor thermal spring than in territories of zonal habitats. For example, similar processes were observed in Kunashir Island (Russian Far East) (Potapov et al. 2014a).

Our conclusion is that the area of Pymvashor thermal springs supports a larger number of bumblebee species than is typical of the surrounding tundra habitat, and that reflects the greater physical and floristic diversity of the thermal area. The ecosystem of Pymvashor, which is formed under the influence of thermal exposure, is a kind of "reserve habitat" (Lobkova \& Lobkov 2003) for the typical zonal species of insects and for the inhabitants from the more southern areas.

We can assume that bumblebee species, which are common within the taiga zone and not typical for tundra habitats, may represent relict populations, from a time when the climate was generally warmer in this area. During the Holocene thermal maximum on the eastern outskirts of the modern Bolshezemelskaya tundra was represented by the taiga zone (Velichko 2002). Hence, the Pymvashor thermal area became "a reserve habitat" for the bumblebee species of the taiga zone later when the climate became cooler.

Acknowledgements. The authors express their appreciation to A. E. Skopin (PhD, the lead researcher of the Department of Animal Ecology, Institute of Hunting and Animal
Breeding of the Russian Academy of Agricultural Sciences, a member of Russian Botanical Society), R. I. Gutiev (senior engineer of the Limited liability company "Design and development of the expedition"), S. O. Yaylyan (General Director of the Non-Commercial Partnership Off-road Club "Bear") for assistance in collecting bumblebees and for comprehensive assistance in this research. We are grateful also to the staff of the Natural History Museum, London and the Zoological Institute of Russian Academy of Sciences, Saint Petersburg for providing us with the opportunity to examine collections. Special thanks are due to Dr. Matthew Copley for improving the language of the paper. This study was funded by the Russian Foundation for Basic Research, according to the research project No. 16-34-60035 mol_a_dk. This study was supported also by the Federal Agency for Scientific Organisations (No. 0410-2015-0034, No. 0410-2014-0028, No. 0410-2014-0025), the Ural Branch of Russian Academy of Sciences (No. 15-12-5-24, No. 0410-2015-0032) and grants from the President of Russia (MD-7660. 2016.5), the Russian Foundation for Basic Research (No. 16-05-00854 a).

\section{References}

Bäckman, J. P. \& Tiainen, J. 2002: Habitat quality of field margins in a Finnish farmland area for bumblebees (Hymenoptera: Bombus and Psithyrus). - Agriculture, Ecosystems and Environment 89: 53-68.

Bolotov, I. N. \& Bogolitsyn, K. G. (ed.) 2011: (Operation of subarctic hydrothermal systems in the winter period.). - Ural Branch of Russian Academy of Sciences, Ekaterinburg. 252 pp. [In Russian.]

Bolotov, I. N. \& Kolosova, Yu. S. 2006: Trends in the formation of biotopic complexes of bumblebees (Hymenoptera, Apidae: Bombini) in northern taiga karst landscapes of the Western Russian Plain. - Russian Journal of Ecology 37(3): 156-166.

Bolotov, I. N. \& Podbolotskaya, M. V. 2003: Local fauna of bumblebees (Hymenoptera: Apidae, Bombini) in the Europe in North of Russia: the Solovetsky Islands. - Vestnik Pomorskogo Universiteta, Seriya estestvennye i tochnye nauki 1(3): 74-87. [In Russian with summary in English.]

Bolotov, I. N., Surso, M. V., Filippov, B. Yu., Gofarov, M. Yu. \& Tarakanov, A. M. 2012: Changes in tree stands on isolated forest islands in the East of Bolshezemelskaya Tundra for the last 100 years in a changing climate. - Lesnoy Zhurnal 5: 30-37. [In Russian with summary in English.]

Bossert, S. 2015. Recognition and identification of bumblebee species in the Bombus lucorum-complex (Hymenoptera, Apidae) - A review and outlook. - Deutsche Entomologische Zeitschrift 62(1): 19-28.

Byvaltsev, A. M. 2009: (Bumblebees (Hymenoptera: Apidae, Bombini) of forest-steppe and steppe in the southern West-Siberian Plain: fauna and community. $\mathrm{PhD}$ thesis.). - Institute of systematics and animal ecology, Novosibirsk. 21 pp. [In Russian.] 
Chernov, Yu. I. 1966: (Complex of anthophilous insects in the tundra zone.). - Voprosy geografii 69: 76-97. [In Russian.]

Elven, R. 2016: Annotated Checklist of the Panarctic Flora (PAF). Vascular plants. URL http://nhm2.uio.no/paf/. (Site visited on 31 August, 2016)

Garbuz, D. G., Zatsepina, O. G, Przhiboro, A. A., Yushenova, I., Guzhova, I. V. \& Evgen'ev, M. B. 2008: Larvae of related Diptera species from thermally contrasting habitats exhibit continuous up-regulation of heat shock proteins and high thermotolerance. - Molecular Ecology 17: 4763-4777.

Glazier, D. S. \& Gooch, J. L. 1987: Macroinvertebrate assemblages in Pennsylvania (USA) springs. - Hydrobiologia 150: 33-43.

Hines, H. M. 2008: Historical biogeography, divergence times, and diversification patterns of bumblebees (Hymenoptera: Apidae: Bombus). — Systematic Biology 57: 58-75.

Levchenko, T. V. \& Tomkovich, K. P. 2014: Contribution to the bee fauna (Hymenoptera: Apiformes) of the Khanty-Mansi Autonomous Region, Western Siberia, Russia. - Entomofauna: Zeitschrift für Entomologie 35(5): 85-100.

Lobkova, L. E. \& Lobkov E. G. 2003: (Role of biological components in ecosystems of the thermal fields of Uzon and Valley of Geysers, and some aspects of protections of thermal ecosystems.) - Conservation of biodiversity of Kamchatka and coastal waters. Materials of III scientific conference: 258-262. [In Russian.]

Løken, A. 1973: Studies on Scandinavian bumblebees (Hymenoptera, Apidae). — Norsk Entomologisk Tidsskrift 20(1): 1-218.

Løken, A. 1984: Scandinavian species of the genus Psithyrus Lepeletier (Hymenoptera, Apidae). - Entomologica Scandinavica 23: 1-45.

Magurran, A. E. 2004: Measuring biological diversity. Blackwell Publishing, Oxford. 215 pp.

Pamilo, P., Tengö, J., Rasmont, P., Pirhonen, K., Pekkarinen, A. \& Kaarnama, E. 1997: Pheromonal and enzyme genetic characteristics of the Bombus lucorum species complex in northern Europe. - Entomologica Fennica 7: 187-194.

Panfilov, D. V. 1978: (The keys for the species of Family Apidae - Bees.). - In: Medvedev, G. S. (ed.), (The keys for insects of the European part of USSR) 3(1): 508-519. Nauka, Leningrad. 584 pp. [In Russian.]

Panfilov, D. V. 1981: Bombus Latreille, 1802. Hymenoptera, Apoidea, Apidae. - In: Gorodkov, K. B. (ed.), Provisional Atlas of the Insects of the European part of USSR. Maps 73-125: 22-28. Nauka, Leningrad. 57 pp. [In Russian.]

Panfilov, D. V. 1982: Bombus Latreille, 1802. Hymenoptera, Apoidea, Apidae. - In: Gorodkov, K. B. (ed.), Provisional Atlas of the Insects of the European part of USSR. Maps 126-178: 25-28. Nauka, Leningrad. 77 pp. [In Russian.]

Panfilov, D. V. 1984: Bombus Latreille, 1802. Hymenopte- ra, Apoidea, Apidae. - In: Gorodkov, K. B. (ed.), Provisional Atlas of the Insects of the European part of USSR. Maps 179-221: 28-32. Nauka, Leningrad. 61 pp. [In Russian.]

Pekkarinen, A. \& Teräs, I. 1993: Zoogeography of Bombus and Psithyrus in north-western Europe (Hymenoptera, Apidae). - Annales Zoologici Fennici 30: 187-208.

Potapov, G. S., Kolosova, Yu. S. \& Bolotov, I. N. 2014a: The structure of bumblebee communities (Hymenoptera, Apidae, Bombus spp.) in some ecosystems of Kunashir Island and Southern Sakhalin (Russian Far East). - Russian Journal of Ecology 45(4): 304-307.

Potapov, G. S., Kolosova, Yu. S. \& Gofarov, M. Yu. 2014b: Zonal distribution of bumblebee species (Hymenoptera, Apidae) in the North of European Russia. - Entomological Review 94(1): 79-85.

Pritchard, G. 1991: Insects in thermal springs. - Memoirs of the Entomology Society of Canada 155: 89-106.

Pritchard, G. \& Kortello, A. 1997: Roosting, perching, and habitat selection in Argia vivida Hagen and Amphiagrion abbreviatum (Selys) (Odonata: Coenagrionidae), two damselflies inhabiting geothermal springs. - Canadian Entomologist 129: 733-743.

Rasmont, P. 1984: Les bourdons du genre Bombus Latreille sensu stricto en Europe occidentale et central. Spixiana 7: 135-160.

Rasmont, P. \& Iserbyt, S. 2010: Genus Bombus. Atlas of the European Bees. STEP Project. Atlas Hymenoptera. URL http://www.atlashymenoptera.net. (Site visited on 31 August, 2016)

Rasmont, P. \& Terzo, M. 2010: Catalogue et clé des sousgenres et espèces du genre Bombus de Belgique et du nord de la France (Hymenoptera, Apoidea). - Université de Mons, Laboratoire de Zoologie, Mons. 25 pp.

Resh, V. H. \& Barnby, M. A. 1984: Distribution of shore bugs and shore flies at Sylvan springs, Yellowstone National Park. — Great Basin Naturalist 44 (1): 99 103.

Stockner, J. G. 1971: Ecological Energetics and Natural History of Hedriodiscus truquii (Diptera) in Two Thermal Spring Communities. - Journal of the Fisheries Research Board of Canada 28 (1): 73-94.

Velichko, A. A. (ed.) 2002: Dynamics of terrestrial landscape components and inland and marginal seas of Northern Eurasia during the last 130,000 years. Atlasmonograph Evolution of landscapes and climates of Northern Eurasia. Late Pleistocene-Holocene-elements of prognosis. II. General paleogeography. GEOS, Moscow. 296 pp. [In Russian.]

Vinogradova, V. M. 1962: (Flora of the thermal springs Pym-Va-Shor in the Bolshezemelskaya Tundra.). Vestnik Leningradskogo Universiteta, Seriya biologicheskaya 9 (2): 22-34. [In Russian.]

Williams P. H. 2016: Bumblebees of the world. URL http://www.nhm.ac.uk/research-curation/projects/bombus/index.html. (Site visited on 31 August, 2016) 